\title{
Pemberdayaan Sampah Plastik di Desa Handil Terusan Menjadi Ecobrick
}

\author{
Miranti Rasyid1, Alifa Sukma Al-Insyirah² \\ 1,2 Fakultas Ilmu Sosial dan Ilmu Politik, Universitas Mulawarman \\ *e-mail: miranti.rasyid@fisip.unmul.ac.id ${ }^{1}$, alifasukma99@gmail.com²
}

\begin{abstract}
The issue raised in the Extraordinary Conditions Community Service Program 2020 is the use of waste into ecobricks which aims to develop village potential through the use of plastic that can be recycled into craft materials or objects that can be useful for everyday life. This community service program uses the interview method to the village party through face-to-face meetings. The steps for implementing the community service program are conducting in-depth interviews, analyzing interview results, conducting focus group discussions, collecting plastic waste, assembling ecobricks. The result of the community service program is that plastic waste that takes a long time to decompose can be useful to become useful objects that are economically viable and become village potential.
\end{abstract}

Keywords: Ecobricks; plastic waste; community dedication.

\begin{abstract}
Abstrak
Permasalahan yang diangkat dalam Program Pengabdian kepada Masyarakat Kondisi Luar Biasa tahun 2020 adalah pemanfaatan sampah menjadi ecobrick yang bertujuan untuk mengembangkan potensi desa melalui pemanfaatan plastic yang dapat didaur ulang menjadi bahan kerajinan atau benda yang dapat bermanfaat untuk kehidupan sehari-hari. Program pengabdian kepada masyarakat ini menggunakan metode wawancara kepada pihak desa melalui pertemuan tatap muka. Langkah-langkah pelaksanaan program pengabdian masyarakat dengan melakukan depth interview, analisis hasil wawancara, melakukan focus group discussion, pengumpulan sampah plastik, perakitan ecobrick. Hasil dari program pengabdian masyarakat ialah Sampah plastik yang membutuhkan waktu lama untuk terurai dapat bermanfaat untuk menjadi benda bermanfaat bernilai ekonomis dan menjadi potensi desa.
\end{abstract}

Kata kunci: Ecobrick; sampah plastik; pengabdian masyarakat.

\section{PENDAHULUAN}

Sampah menjadi salah satu masalah terbesar yang dialami banyak daerah di Indonesia, Sampah plastik merupakan salah satu permasalahan yang belum dapat di atasi dilingkungan Indonesia (Suminto, 2017). Indonesia merupakan peringkat kedua di dunia sebagai negara penghasil sampah plastik ke laut setelah Tiongkok dengan jumlah 10,95 juta lembar sampah kantong plastik yang sama artinya dengn luasan 65,7 Ha kantong plastik atau sama dengan 60 kali luas lapangan sepakbola (Astuti, 2016).

Kemasan makanan, minuman, kemasan consumer goods, kantong belanja, serta pembungkus barang lainnya yang merupakan sumber utama sampah plastic (Salamah, Amalia, \& Rahayu, 2019). Dari total timbunan plastik, hanya $10-15 \%$ saja yang telah didaur ulang, $60-70 \%$ ditimbun ditempat pembuangan akhir, dan 15-30\% belum terkelola sampai terbuang ke lingkungan terutama perairan seperti sungai, danau, pantai, dan laut (Asih \& Primasari, 2019).

Dibandingkan material lain, plastik memiliki keunggulan seperti kuat, ringan, fleksibel, tahan karat, tidak mudah pecah, mudah diberi warna, mudah dibentuk, serta isolator panas dan listrik yang baik (Arico \& Jayanthi, 2018). Namun, plastik sudah menjadi sampah dapat menjadi dampak negatif pada lingkungan karena plastik sangat sulit untuk terurai, dapat menurunkan kesuburan tanah, dan dapat menyebabkan banjir apabila dibuang sembarangan (Qomariah \& Nursaid, 2020). Sampah plastik juga akan mengeluarkan zat-zat yang berbahaya bagi kesehatan manusia apabila sampah itu dibakar (Asih \& Fitriani, 2018). 
Hal ini juga terjadi di Desa Handil Terusan Kecamatan Anggana Kabupaten Kutai Kartanegara Provinsi Kalimantan Timur. Desa Handil Terusan terletak di Kecamatan Anggana Kabupaten Kutai Kartanegara berdiri tahun 2008 dengan (perkiraan) jumlah penduduk 1300 kepala keluarga. Pekerjaan penduduk di Desa/Kecamatan pada umumnya adalah Nelayan dan Petani Potensi desa/kecamatan yang teramati adalah perikanan air tawar (Nuris \& Syahrani, 2021). Berdarkan hasil wawancara dnegan pihak kantor Desa Handil Terusan bahwasanya masyarakat Desa Handil Terusan masih sering membuang sampah mereka ke sungai atau ke lahan kosong yang banyak terdapat di desa. Tidak hanya sampah rumah tangga organik yang mudah diuraikan, namun masyarakat Desa Handil Terusan juga membuang sampah anorganik seperti plastik.

Sampah plastik sendiri menjadi salah satu jenis sampah yang tidak mudah terurai dan membutuhkan waktu yang sangat lama untuk dapat hancur (Hutauruk, 2019). Selain lamanya waktu yang dibutuhkan untuk mengurai sampah plastik, sampah tersebut juga sangat berbahaya bagi mahluk hidup dan penanggulangan dengan cara dibakar dapat menyebabkan polusi udara (Marliani, 2015).

Hal tersebut dipertegas oleh Pusat Data dan Analisa Tempo (2019) yang menyatakan "Plastik tak bisa hancur lewat proses alami dan bertahan sangat lama di alam, dibutuhkan 5001000 tahun bagi plastik agar terdegradasi tapi tetap saja akan menyisakan partikel mikroplastik yang berbahaya bagi mahluk hidup. Pemusnahan secara konvensional, seperti dibakar, hanya akan menambah kadar polutan di udara." Hal ini sesuai menurut Suminto (2017) yang menyatakan bahwa sampah plastik sulit untuk terurai dan apabila dibakar akan menghasilkan gas beracun berupa dioxyne yang dapat mencemari udara melalui asap dan mencemari air melalui abu.

Oleh karena itu dibutuhkan pengolahan sampah plastik yang tepat agar pencemaran dapat ditanggulangi dan masyarakat mendapatkan keuntungan dari pengolahan sampah plastik tersebut (Utami \& Ningrum, 2020). Salah satu cara menanggulangi pencemaran lingkungan oleh sampah plastik di Desa Handil terusan adalah memanfaatkan sampah plastik tersebut menjadi ecobrick.

Ecobrick adalah sebuah botol plastik yang dikemas dengan memasukkan potongan plastik bekas dalam kondisi bersih dan kering dengan kepadatan tertentu yang dapat digunakan untuk membuat suatu karya seni maupun bangunan yang berdaya guna tinggi (Istirokhatun \& Nugraha, 2019). Selain itu, Ecobrick adalah pemanfaatan botol plastik bekas yang diisi hingga padat oleh sampah non- biological seperti kantong kresek ataupun plastik sisa pembungkus makanan diaman hasil pengisian tersebut dapat dimanfaatkan menjadi blok bangunan ataupun disusun menjadi benda lain seperti meja dan kursi (Purwandito, Mutia, \& Lydia, 2020)

Singkatnya Ecobrick adalah salah satu solusi terbaik untuk penanggulangan sampah karena dapat mengurangi sampah dalam jumlah besar yang mana hasilnya dapat dimanfaatkan masyarakat dalam jangka waktu yang lama (Sidiq, 2017). Hal ini sesuai dengan salah satu penyelesaian masalah sampah plastik yang ada di Surabaya yaitu dengan pemisahan sampah organik dan sampah non organik dikelola menjadi barang dengan nilai ekonomis seperti daur ulang plastik menjadi kantong plastik craftis (Ecobag) dengan nilai keindahan sebagai daya tarik di unit bisnis (Haryono \& Untarini, 2018)

Berdasarkan latar belakang yang telah dipaparkan program kerja ini ditujukan seluruh masyarakat Desa Handil Terusan. Tujuan dari program kerja ini ialah masyarakat Desa Handil Terusan dapat memanfaatkan sampah plastik menjadi ecobrick untuk keberlangsungan kehidupan, memaksimalkan per-ekonomian, meningkatkan daya jual parawisata desa. 


\section{METODE}

Metode pendekatan yang digunakan adalah melalui metode wawancara bersama pihak Desa Handil Terusan yang mana diawali dengan wawancara awal lalu penentuan TSO. Penentuan TSO ini dilakukan dengan cara analisis permasalahan utama dari Desa yang mana berdasarkan hasil wawancara adalah permasalahan tidak terkendalinya sampah plastik di desa. Selain itu, analisis permasalahan ini berdasarkan data dari jurnal dan hasil wawancara. Sehingga pengabdian masyarakat yang kami lakukan berdasarkan kebijakan yaitu dilakukan secara daring atau online. Program kerja ini dipublikasikan ke media sosial seperti Instagram dan Youtube.

\section{Urutan Penyelesaian Masalah}

Berdasarkan hasil wawancara yang kami lakukan dengan pihak Desa Handil Terusan secara langsung megenai permasalahan perilaku yang tejadi di masyarakat desa. Maka, langkah langkah untuk menyelesaikan masalah tersebut sebagai berikut:

1. Langkah 1 : Wawancara awal penentuan TSO, didapatkan program kerja yang menjadi program pengabdian masyarakat yaitu pemanfaatan sampah menjadi ecobrick.

2. Langkah 2 : Analisis hasil wawancara yang mana merupakan penitik berat dari topik wawancara yaitu permasalahan sampah plastik desa.

3. Langkah 3 : Diskusi penentuan penyelesaian masalah dari sampah plastik yaitu mencari alternatif penyelesaian masalah di daerah lain. Hasil diskusi ini adalah dengan cara pemanfaatan sampah plastik menjadi ecobrick.

4. Langkah 4 : Pengumpulan bahan untuk pembuatan ecobrick. Hasil dari pengumpulan ini didapatkan sebanyak 13 botol air mineral berukuran $600 \mathrm{ml}$ dan 18 botol air mineral berukuran $1.5 \mathrm{~L}$ serta $11 \mathrm{~kg}$ kantong plastik.

5. Langkah 5 : Perakitan ecobrick yang mana dilakukan semua anggota kelompok, hal ini untuk mengefektivitaskan perakitan ecobrick. Hasil dari perakitan ini didapatkan 1 meja berukuran $3 \times 4$ dari botol berukuran $600 \mathrm{ml}$ dan 1 bangku berukuran $4 \times 3$ dari botol berukuran $1.5 \mathrm{~L}$.
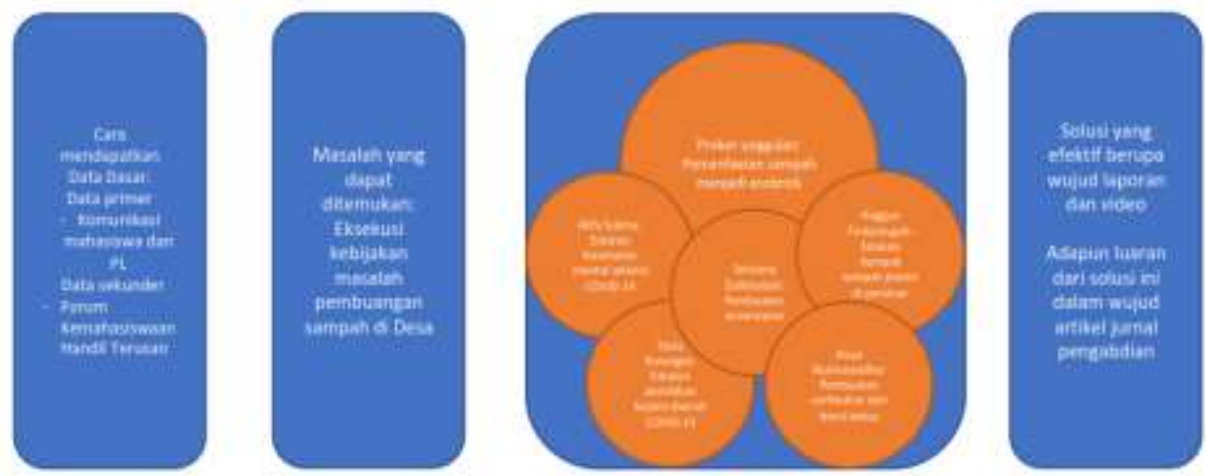

Gambar 1. Bagan Penyelesaian Masalah.

\section{HASIL DAN PEMBAHASAN}

Hasil Dari Langkah 1 Penyelesaian Masalah

Metode yang pertama kali kami lakukan adalah Melakukan depth interview dengan pihak perwakilan Desa Handil Terusan sebagai penentuan TSO. Pihak terkait yang terlibat dalam langkah 1 ini yaitu pelaksaan depth interview terdiri dari sekretaris desa, kepala dusun desa, ketua forum kemahasiswaan Desa Handil Terusan. Pertemuan ini diberlangsungkan dengan pertemuan 
langsung datang ke lapangan bersama perwakilan desa dengan keterangan mahasiswa perwakilan adalah orang yang berdomisili Kutai Kartanegara (sekabupaten). Pemilihan dari pengambilan data dengan cara terjun ke lapangan langsung melakukan depth interview karena wawancara adalah pertemuan dua orang untuk bertukar informasi dan ide melalui tanya jawab, sehingga dapat dikonstruksikan makna dalam suatu topik tertentu (Sugiyono, 2013). Selain itu kami juga melakukan pengecekan keabsahan data antara data riil dan data hasil wawancara dengan observasi. Observasi atau pengamatan dilakukan dengan tujuan mendapatkan data suatu masalah secara visual sehingga diperoleh pemahaman terhadap informasi atau keterangan yang diperoleh sebelumnya (Arikunto, 2010). Hasil dari diskusi ini adalah didapatkan informasi mengenai desa. Lesson learned yang diperoleh adalah bahwa Desa Handil Terusan mengalami kesulitan di bidang penanganan sampah.

Hasil Dari Langkah 2 Penyelesaian Masalah

Metode yang kedua kami lakukan yaitu mengnalisis hasil wawancara yang mana merupakan penitik berat dari topik wawancara yaitu permasalahan sampah plastik desa. Pihak yang terlibat dalam langkah kedua adalah seluruh tim pengabdian masyarakat. Pemilihan langkah berupa pertemuan tatap muka langsung untuk melakukan analisis secara langsung apa yang menjadi permasalahan utama melalui diskusi kelompok. Melalui metode diskusi ini, tim pengabdian masyarakat bisa saling bertukar pikir dalam menentukan program pengabdian masyarakat yang sesuai dengan keadaan desa bukan hanya sekedar program biasa. Hasil dari diskusi ini didapatkan permasalahan utama yaitu sampah plastik yang mana itu dibenarkan oleh pihak desa. Langkah ini memberikan lesson learned yaitu rencana program kerja yang bersifat menyesuaikan kondisi desa tidak hanya serta ide biasa apakah itu dibutuhkan desa atau tidak melainkan sangat dibutuhkan sekali.

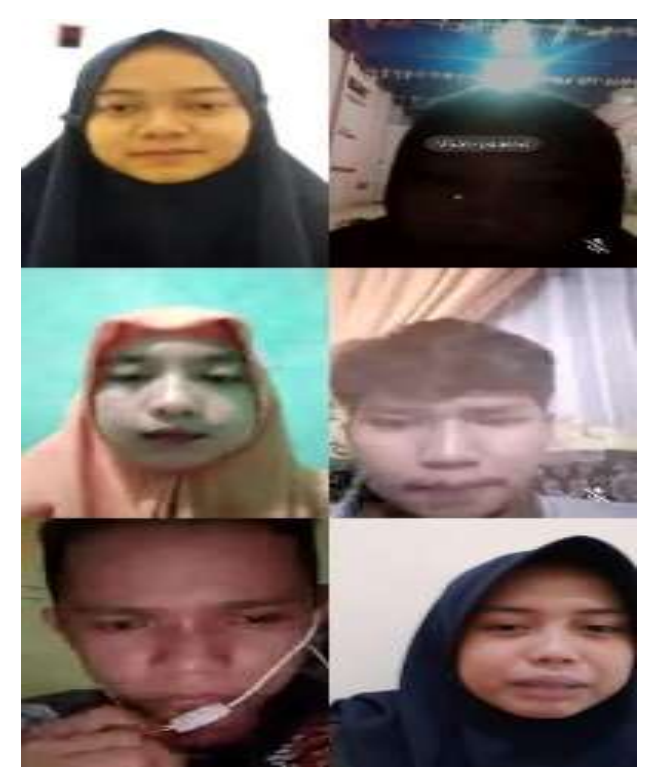

Gambar 2. Bukti Pelaksaan Dari Langkah 2 Penyelesaian Masalah

Hasil Dari Langkah 3 Penyelesaian Masalah

Metode yang ketiga ini berdiskusi penentuan penyelesaian masalah dari sampah plastik yaitu mencari alternatif penyelesaian masalah di daerah lain. Hasil diskusi ini adalah dengan cara pemanfaatan sampah plastik menjadi ecobrick. Pihak yang terlibat dalam diskusi ini adalah seluruh tim pengabdian masyarakat melalui pertemuan tatap muka secara langsung untuk meningkatkan efektivitas dalam berdiskusi. Pengambilan metode focus group discussion ini untuk meningkatkan efektivitas dalam berdiskusi karena lebih kaya akan pendapat dari semua pemikiran individu mengenai suatu fenomena. Definisi awal tentang metode FGD menurut Kitzinger \& Barbour (1999) adalah melakukan eksplorasi suatu isu/fenomena khusus dari diskusi 
suatu kelompok individu yang berfokus pada aktivitas bersama diantara para individu yang terlibat didalamnya untuk menghasilkan suatu kesepakatan bersama. Dikatakan keunggulan penggunaan metode FGD adalah memberikan data yang lebih kaya dan memberikan nilai tambah pada data yang tidak diperoleh ketika menggunakan metode pengumpulan data lainnya (Lehoux dkk, 2006). Maka dari itu kami menggunakan metode ini dalam mendiskusikan penentuan penyelesaian masalah ini. Hasil diskusi ini didapatkan program pengabdian masyarakat ini yaitu cara pemanfaatan sampah plastik menjadi ecobrick yang mana ini merupakan tidak bertujuan memusnahkan sampah plastik melainkan menggunakan kebermanfaatan sampah. Langkah ini memberikan lesson learned yaitu ketepatan dari program kerja ini yang tepat dengan urgensi desa.

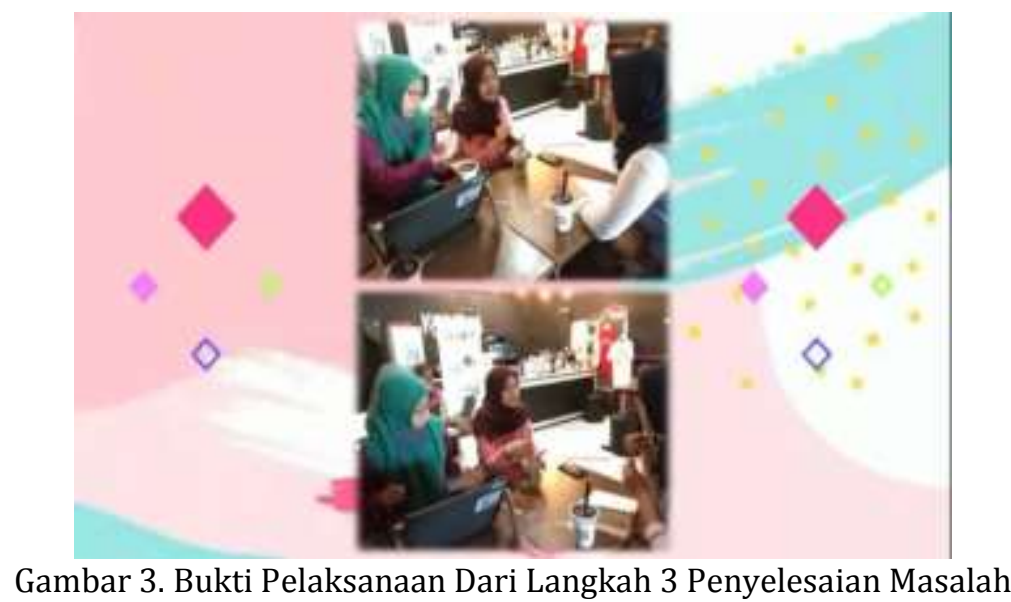

Hasil Dari Langkah 4 Penyelesaian Masalah

Metode yang keempat kami yang kami lakukan adalah pengumpulan bahan untuk pembuatan ecobrick. Hasil dari pengumpulan ini didapatkan sebanyak 13 botol air mineral berukuran $600 \mathrm{ml}$ dan 18 botol air mineral berukuran $1.5 \mathrm{~L}$ serta $11 \mathrm{~kg}$ kantong plastik. Metode pengumpulan sampah ini berlangsung di rumah masing-masing dan adanya bantuan sampah plastik rumahan dari guest house sangat membantu kami dalam keberlangsungan pengumpulan sampah plastik ini. Pemilihan metode pemanfaatan sampah plastik menjadi ecobrick adalah seperti yang diketahui bahwa sampah plastik tidak mudah terurai baik di daratan maupun di perairan, pada masyarakat di Surabaya diberlakukan pemanfaatan sampah menjadi craftis dengan nilai ekonomis untuk masyarakat (Haryono \& Untarini, 2018). Memanfaatkan sampah menjadi ecobrick sebenarnya bukan memutus rantai dengan pemusnahan melainkan memperpanjang umur plastik agar terurai dengan alami sehingga menjadi barang yang bernilai ekonomis serta bermanfaat (Suminto, 2017).

Lalu pengumpulan sampah dilakukan dengan cara mencari sampah langsung di rumah masing-masing sebagai media sosialisasi di masyarakat sekitar mengenai ecobrick secara tidak langsung. Hasil dari kegiatan pengumpulan sampah ini didapatkan sebanyak 13 botol air mineral berukuran $600 \mathrm{ml}$ dan 18 botol air mineral berukuran $1.5 \mathrm{~L}$ serta $11 \mathrm{~kg}$ kantong plastik. Langkah ini memberikan dampak pengurangan sampah plastik di rumah masing-masing menjadi benda bermanfaat yang akan dirakit menjadi ecobrick nanti selain itu guest house menjadi tidak perlu sulit membuang sampah plastik ke pembuangan akhir melainkan menjadi benda bermanfaat.

Hasil Dari Langkah 5 Penyelesaian Masalah 
Metode yang kelima kami melakukan perakitan ecobrick yang mana dilakukan oleh tim pengabdian masyarakat, hal ini untuk mengefektivitaskan perakitan ecobrick. Hasil dari perakitan ini didapatkan 1 meja berukuran $3 \times 4$ dari botol berukuran $600 \mathrm{ml}$ dan 1 bangku berukuran $4 \times 3$ dari botol berukuran 1.5L. Seperti yang dijelaskan pada langkah 4, pemilihan ecobrick ini dikarenakan pemanfaatan sampah melalui ecobrick tidak hanya memperpanjang usia plastik menjadi suatu benda melainkan melainkan menjadi suatu benda yang bernilai ekonomis (Suminto, 2017).

Pemilihan metode ini dilaksanakan dengan langkah awal memasukkan sampah ke dalam botol dengan padat hingga bobot ecobrick seberat 200gr untuk botol ukuran $600 \mathrm{ml}$ dan $500 \mathrm{gr}$ untuk botol ukuran 1.5L. Lalu lanjut ke langkah selanjutnya yaitu penyusunan botol dengan tinggi yang sama lalu direkatkan satu sama lain membentuk benda seperti kursi dan meja. Hasil barang yang seperti ini menjadi benda yang bersifat ekonomis dan menjadi potensi desa dalam pengembangan keterampilan dan wirausaha (Haryono \& Untarini, 2018). Hasil dari perakitan ini didapatkan keberhasilan 1 meja dan 1 kursi. Langkah ini memberikan dampak positif yaitu menghasilkan benda yang bermanfaat dan lesson learned dari ecobrick ini bahwa sampah plastik ternyata memiliki nilai ekonomis dan kebermanfaatan yang bagus.

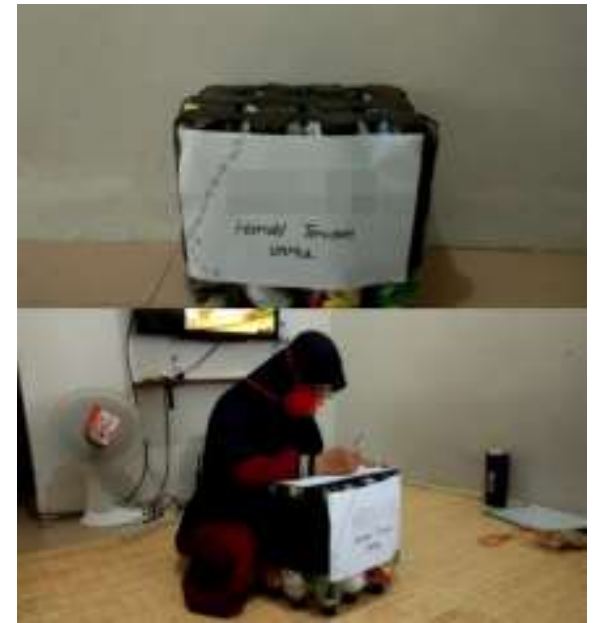

Gambar 4. Bukti Pelaksaan Dari Langkah 5 Penyelesaian Masalah

\section{KESIMPULAN}

Hasil dari program kerja kami adalah Permasalahan dari sebuah desa tidak dapat hanya ditentukan dari masalah saja namun dilihat dari tingkat urgensi desa tersebut. Melakukan diskusi grup yang terfokus membantu dalam penganalisisan hasil wawancara yang digunakan sehingga lebih efektif ketika menentukan alternative penyelesaian masalah. Sampah plastik merupakan permasalahan utama dari Desa Handil Terusan sehingga memanfaatkan sampah plastik merupakan solusi dari pengurangan limbah plastik ini yaitu melalui ecobrick. Ecobrick tidak hanya mengurangi sampah plastik menjadi barang bermanfaat melainkan menjadi barang bersifat ekonomis sehingga menjadikan salah satu potensi desa nantinya.

\section{UCAPAN TERIMA KASIH}

Terima kasih diucapkan kepada Desa Handil Terusan, Provinsi Kalimantan Timur beserta masyarakatnya, dan pihak-pihak yang membantu proses penelitian

\section{DAFTAR PUSTAKA}

Arikunto, S. (2010). Prosedur penelitian: suatu pendekatan praktik. Jakarta: Penerbit Rineka Cipta. 
Arico, Z., \& Jayanthi, S. (2018). Pengolahan limbah plastik menjadi produk kreatif sebagai peningkatan ekonomi masyarakat pesisir. Martabe: Jurnal Pengabdian Kepada Masyarakat, 1(1), 1-6.

Asih, H. M., Fitriani, S. (2018). Penyusunan standard operating procedure (SOP) produksi produk inovasi ecobrick. Jurnal Ilmiah Teknik Industri. 17(2): 144-150

Asih, H. M., \& Primasari, I. A. (2019, November). Pemberdayaan masyarakat melalui peningkatan efisiensi dan efektivitas pada produksi daur ulang sampah plastik. In Seminar Nasional Hasil Pengabdian Kepada Masyarakat (pp. 309-318).

Astuti, A. D. (2016). Penerapan kantong plastik berbayar sebagai upaya mereduksi penggunaan kantong plastik. Jurnal Litbang: Media Informasi Penelitian, Pengembangan dan IPTEK, 12(1), 32-40.

Haryono, N. A., Untarini, N. (2018). Pelatihan produk daur ulang sampah plastik. Jurnal Pengabdian Masyarakat. 2(1): 27-40

Hutauruk, T. R. (2019). Manajemen Inovasi sebagai solusi kebijakan terhadap persoalan sampah plastik di kota Samarinda. Jurnal Riset Inossa, 1(1), 1-12.

Kitzinger, J. (1994). The methodology of focusgroup interviews: the importance of interaction between research participants. Sociology of Healthand Illness, 16: 103-121.

Lehoux, P., Poland, B., \& Daudelin, G. (2006). Focus group research and "the patient's view. "Social Science \& Medicine, 63: 2091-2104.

Marliani, N. (2015). Pemanfaatan limbah rumah tangga (sampah anorganik) sebagai bentuk implementasi dari pendidikan lingkungan hidup. Formatif: Jurnal Ilmiah Pendidikan $M I P A, 4(2)$.

Nuris, M. S., \& Syahrani, R. A. (2021). Akulturasi Komunikasi Masyarakat Suku Bugis dan Suku Banjar di Desa Handil Terusan, Kalimantan Timur. Jurnal Audience: Jurnal Ilmu Komunikasi, 4(01), 60-72.

Purwandito, M., Mutia, E., \& Lydia, E. N. (2020). Pelatihan pemanfaatan limbah plastik menjadi produk bernilai ekonomis pada desa keumuning peut. Global Science Society: Jurnal Ilmiah Pengabdian Kepada Masyarakat, 2(2), 381-388.

Qomariah, N., \& Nursaid, N. (2020). Sosialisasi Pengurangan Bahan Plastik Di Masyarakat. Jurnal Pengabdian Masyarakat Manage, 1(1), 43-55.

Salamah, S., Amalia, S., \& Rahayu, A. (2019, September). Pelatihan management pengelolaan dan pengolahan sampah rumah tangga menjadi bunga hiasan dan bros. In Seminar Nasional Hasil Pengabdian Kepada Masyarakat (pp. 265-272).

Sidiq, A. S. (2017). Peran radio komunitas dalam meningkatkan kebersihan lingkungan (studi pada radio komunitas suara kota bandar lampung di kelurahan kaliawi tanjung karang pusat). (Doctoral dissertation, IAIN Raden Intan Lampung).

Sugiyono. (2007). Memahami penelitian kualitatif. Bandung: Alfabeta.

Suminto, S. (2017). Ecobrick: solusi cerdas dan kreatif untuk mengatasi sampah plastik. Productum: Jurnal Desain Produk. 3(1): 26-34

Tempo. (2019). Berbagai upaya melindungi lingkungan dari sampah plastik. Jakarta: Tempo

Utami, M. I., \& Ningrum, D. E. A. F. (2020). Proses Pengolahan Sampah Plastik di UD Nialdho Plastik Kota Madiun. Indonesian Journal of Conservation, 9(2), 89-95. 